\title{
Meningkatkan Minat Baca Pada Anak Usia Dini
}

\author{
Amelia Haryanti ${ }^{\text {a,1 }}$, Dindin ${ }^{\text {b,2 }}$

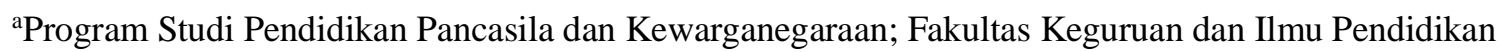 \\ Universita Pamulang, Banten \\ bProgram Studi Teknik Informatika; Fakultas Teknik Universitas Pamulang, Banten \\ ${ }^{1}$ dosen00811@unpam.ac.id; ${ }^{2}$ dosen002573@unpam.ac.id \\ *Korespondensi Penulis
}

Naskah diterima: 23 Agustus 2020, direvisi: 10 September 2020, disetujui: 20 September 2020

\begin{abstract}
Abstrak
Berkembangnya cara dan metode pembelajaran bagi peserta didik tidak serta merta membuat peserta didik menjadi gemar membaca, apalagi seiring dengan pesatnya perkembangan teknologi yang semakin modern, membaca buku menjadi hal yang enggan dilakukan oleh anakanak, karena mereka lebih suka bermain gadget daripada membaca buku. Menyikapi permasalahan ini, kami tim Pengabdian Masyarakat dari program Studi Pendidikan Pancasila Fakultas Keguruan dan ilmu Pendidikan Universitas Pamulang mengadakan Pengabdian Masyarakat pada siswa siswi PAUD Al Amanah yang terletak di Kecamatan Serpong kota Tangerang Selatan. Metode pengabdian kepada masyarakat ini dilakukan dalam bentuk penyuluhan dengan memberikan sosialisasi kepada orang tua dan anak usia dini, khususnya di PAUD Al Amanah tentang pentingnya meningkatkan gemar membaca. Penyuluhan ini disertai dengan tanya jawab peserta penyuluhan kepada narasumber tentang permasalahan yang selama ini dihadapi oleh masyarakat. Dari hasil pengabdian masyarakat ini, diharapkan adanya peningkatan dalam minat baca sebesar $80 \%$ pada anak usia dini, khususnya di PAUD Al Amanah.
\end{abstract}

Kata Kunci; Penyuluhan, minat baca, PAUD

\begin{abstract}
The development of ways and methods of learning for students does not necessarily make students become fond of reading, developing along with the development of increasingly modern technology, reading books is something that children are reluctant to do, and they prefer to play gadgets to read books. Responding to this problem, our Community Service team from the Pancasila Education Study Program of the Teaching and Education Faculty of Pamulang University collects Community Service at Al Amanah PAUD students who are located in Serpong District, South Tangerang City. This community service method is carried out in the form of counseling by giving outreach to parents and young children, especially in Al Amanah PAUD on the importance of improving reading. This counseling discusses the question and answer session of the counselors about the speakers about the conflict that needs to be done by the community. From the results of this community service, it is expected that there is an increase in interest in reading by $80 \%$ in early childhood, especially in Al Amanah PAUD
\end{abstract}

Keywords; Education, interest in reading, PAUD 


\section{PENDAHULUAN}

Semakin meningkatnya perkembangan teknologi masa kini, menjadikan hiburan masyarakat kita beralih mengikuti perkembangan jaman. Banyaknya hiburan di masyarakat melalui barang elektronik yang didapatkan dengan harga terjangkau menjadikan masyarakat menjadi semakin enggan untuk membaca, terutama anak-anak. Mereka lebih tertarik untuk bermain gadget atau menonton televisi. Apalagi sekarang semakin berkembang media sosial yang semakin menjamur dan meracuni pikiran mereka. Setiap anak mempunyai handphone yang tidak digunakan untuk hal positif justru merusak dunia pendidikan. Adanya televisi, handphone, komputer dan barang-barang elektronik lainnya menjadi hiburan yang menarik bagi masyarakat, tidak terkecuali anak-anak. Anak-anak lebih suka menonton televisi dan bermain gadget daripada membaca buku mereka.

Membaca merupakan hal yang paling diperlukan jika seseorang ingin mengetahui apa yang sedang terjadi saat ini. siswa. Namun hal tersebut tidak membantu banyak, bahkan peran perpustakaan cenderung mati. Untuk mengatasi hal tersebut diperlukan alternatif solusi yang dapat mengatasi masalah minat baca ini secara efektif dan efisien. Membaca adalah suatu hal yang dianggap menyebalkan bagi anak. Sekolah pun jika tidak ada pekerjaan rumah yang harus mereka kerjakan membuat anak malas untuk belajar bahkan malas untuk sekedar membaca. Jika hal ini terus dibiarkan maka tujuan dari pendidikan nasional Indonesia tidak akan tercapai. Oleh karena itu, guru perlu merancang pembelajaran membaca dengan baik sehingga mampu menumbuhkan kebiasaan membaca sebagai suatu yang menyenangkan. Suasana belajar harus dapat diciptakan melalui kegiatan permainan bahasa dalam pembelajaran membaca. Hal itu sesuai dengan karakteristik anak yang masih senang bermain. Permainan memiliki peran penting dalam perkembangan kognitif dan sosial anak.

Membaca merupakan salah satu keterampilan berbahasa yang diajarkan di sekolah. Terdapat dua kelompok keterampilan membaca, yaitu : 1 . Keterampilan yang bersifat menerima (reseptif) yang meliputi keterampilan membaca dan menyimak., 2. Keterampilan yang bersifat mengungkap (produktif) yang meliputi keterampilan menulis dan berbicara.

Minat merupakan hal yang sangat penting dalam pembelajaran. Menurut Hawadi (2001), minat adalah kesenangan atau perhatian yang terus-menerus terhadap suatu objek karena adanya pengharapan akan 
memperoleh kemanfaatannya. Aspek minat terdiri dari aspek kognitif dan aspek afektif. Aspek kognitif berupa konsep positif terhadap suatu objek dan berpusat pada manfaat dari objek tersebut. Aspek afektif nampak dalam rasa suka, tidak senang dan kepuasan pribadi terhadap objek tersebut. Minat menunjukan rasa ingin tahu siswa dibangkitkan dibangkitkan dan dipelihara secara terus menerus sepanjang kegiatan pembelajaran. Membangkitkan minat belajar berarti membangkikan rasa ingin tahu siswa dan mempertahankan rasa ingin tahu sepanjang kegiatan proses pembelajaran. Faktor-faktor yang menentukan perkembangan minat, tidak selalu tampak dengan jelas sebab faktor yang mempengaruhinya bersifat lebih tidak tampak seperti kebutuhan-kebutuhan yang tidak didasari perasaan agresif, keinginankeinginan dan lain sebagainya.

Minat tidak selalu tampak dengan jelas karena adanya faktor yang selalu mempengaruhinya. Menurut Hilgard (dalam Slamento. 2004) minat adalah Interest in persisting tendency to pay attention to and enjoy some activity or content, minat adalah kecenderungan seseorang untuk memperhatikan dan mengenang beberapa kegiatan. Minat menunjukan rasa ingin tahu siswa dibangkitkan dibangkitkan dan dipelihara secara terus menerus sepanjang kegiatan pembelajaran.

Minat tidak selalu tampak dengan jelas sebab faktor yang mempengaruhinya bersifat lebih tidak tampak seperti kebutuhan kebutuhan, keinginan-keinginan dan lain sebagainya. Suatu petunjuk penting untuk dapat mengetahui apa yang diinginkan oleh anak-anak dan faktor-faktor apa saja yang mempengaruhi kelakuan dan sikapnya adalah dapat diketahui dengan melalui cita-cita dan peniruan akan imitasi dari kelakuan orang dewasa yang dikagumi. Masalah demikian merupakan minat atau kecenderungan anak untuk bereaksi dengan cara tertentu terhadap kelakuan seseorang yang dikagumi itu. Pada umumnya keinginan dan cita-cita anak itu didasarkan pada tiga kebutuhan yaitu Kebutuhan akan perasaan aman. Kebutuhan akan memperoleh status dan Kebutuhan memperoleh penghargaan.

Jadi jelaslah bahwa minat sangat dipengaruhi oleh faktor kebutuhan serta keinginan dan cita-cita seseorang. Minat seseorang biasanya dipengaruhi faktor kebutuhannya terhadap sesuatu misalnya kebutuhan akan perasaan aman, memperoleh status tertentu dalam lingkungan masyarakat dan lingkungan sosialnya dan kebutuhan akan penghargaan. 
Untuk mencapai prestasi yang baik disamping kecerdasan juga minat, sebab tanpa adanya minat segala kegiatan akan dilakukan kurang efektif dan efisien. Dalam percakapan sehari-hari pengertian perhatian dikacaukan dengan minat dalam pelaksanaan perhatian seolah-olah kita menonjolkan fungsi pikiran, sedangkan dalam minat seolah-olah menonjolkan fungsi rasa, tetapi kenyataanya apa yang menarik minat menyebabkan pula kita kita berperhatian, dan apa yang menyebabkan perhatian kita tertarik minat pun menyertai kita. Minat menyebabkan perhatian dimana minat seolaholah menonjolkan fungsi rasa dan perhatian serta fungsi pikiran. Hal ini menegaskan bahwa apa yang menarik minat menyebabkan pula kita berperhatian dan apa yang menyebabkan berperhatian kita tertarik, minatnya menyertainya jadi ada hubungan antara minat dan perhatian. Minat adalah bentuk dari motivasi intrinsik. Pengaruh positif minat akan membuat seseorang mereka tertarik untuk bereksperimen seperti merasakan kesenangan, kegembiraan, dan kesukaan. Seseorang yang memiliki minat terhadap apa yang dipelajari lebih dapat mengingatnya dalam jangka panjang dan menggunakannya kembali sebagai sebuah dasar untuk pembelajaran di masa yang akan datang.
Minat membaca masyarakat Indonesia saat ini sangat rendah. Menurut Menteri Koordinator Bidang Kesejahteraan H.R Agung Laksono prosentase minat baca masyarakat Indonesia hanya sebesar 0,01\%. Artinya dari 10.000 orang Indonesia hanya 1 orang saja yang gemar membaca. 4. Selain itu pemerintah juga berupaya mengembangkan perpustakaan keliling dan koran desa. Harus membuat perpustakaan yang mudah diakses dan membuat masyarakat tertarik dengan perpustakaan, ungkapnya. Diharap dengan upaya itu minat baca masyarakat bisa terdorong naik.

Minat membaca anak Indonesia masih jauh ketinggalan dibanding negara lain seperti Jepang yang mencapai 45 persen. Sedangkan Singapura 55 persen. Keberadaan perpustakaan sekolah yang sepi peminatnya menandai bahwa siswa kurang gemar membaca. Apalagi ditambah dengan pemanfaatan perpustakaan yang kurang maksimal membuat rasa malas membaca itu betah bertahan dalam pikiran siswa. Proses pemecahan masalah dilakukan secara kolaborasi antara peneliti dengan rekan sejawat bersama guru, peneliti bekerja secara tim mulai dari persiapan, pelaksanaan dan pelaporan. Dari latar belakang di atas maka peneliti berupaya untuk "Sosialisasi Meningkatkan Budaya Gemar Membaca dan Sumbangan Buku Bacaan untuk Siswa Siswi 


\section{PAUD AL AMANAH', Serpong Kota}

Tangerang Selatan.

Adapun Tujuan Pengabdian kepada Masyarakat yaitu sebagai berikut ini: pertama, meningkatkan pemahaman kepada masyarakat khususnya siswa/siswi anak usia dini, orang tua siswa, guru dan masyarakat tentang pentingnya peningkatan minat baca bagi anak-anak sejak usia dini. Kedua, mensosialisasikan pentingnya meningkatkan minat baca bagi anak-anak sejak usia dini. Ketiga, meningkatkan kompetensi dosen di bidang pedagogik, profesional, sosial, dan kepribadian.

Sedangkan tujuan eksternal pengabdian kepada masyarakat bagi masyarakat bertujuan sebagai berikut: 1). memberikan pemahaman kepada para anak-anak usia dini, orang tua siswa/siswi, guru dan masyarakat tentang pentingnya meningkatkan minat baca bagi anak usia dini, 2) memberikan pemahaman kepada mereka agar meningkatkan minat baca.

Manfaat dari adanya kegiatan ini adalah bagi guru dan orang tua adalah memudahkan menerapkan gemar membaca bagi peserta didiknya, sedangkan bagi dosen sebagai pelaku pengabdian kepada masyarakat adalah memberikan pengetahuan dan memberikan andil kepada masyarakat, khususnya peserta didik PAUD untuk mensosialisasikan pentingnya rajin membaca.

\section{METODE}

Dalam melaksanakan pengabdian pengabdian masyarakat ini, metode yang digunakan yakni melalui kegiatan penyuluhan. Dalam penyuluhan ini tim Pengabdian kepada Masyarakat (PkM) menyampaikan paparan materi terkait dengan upaya meningkatkan minat baca dikalangan anak. Kegiatan PkM didasarkan pada observasi yang dilakukan oleh tim PkM dengan melakukan wawancara via telepon dengan mitra terkait dengan permasalahan kurangnya minat baca.

Kegiatan Pengabdian kepada Masyarakat dilakukan di PAUD Al Amanah Serpong Kota Tangerang Selatan. Pemilihan lokasi PkM dikarenakan lokasi PAUD sangat strategis dekat dengan Universitas Pamulang. Diharapkan dengan kegiatan $\mathrm{PkM}$ ini dapat memberikan kontribusi nyata perguruan tinggi dengan masyarakat.

Kegiatan PkM dilaksanakan pada bulan Mei 2020. Pelaksanaan PkM dilakukan dengan media Zoom. Hal ini dikarenakan kondisi penyebaran Covid-19 di Kota Tangerang Selatan sehingga pembelajaran dilakukan secara online. 


\section{HASIL DAN PEMBAHASAN}

Pra Kegiatan pengabdian masyarakat dilakukan dengan perizinan kegiatan pengabdian kepada masyarakat yang ditujukan kepada warga PAUD Al Amanah Serpong Kota Tangerang Selatan guna membekali bagaimana warga sekolah baik guru, peserta didik, maupun wali murid memahami pentingnya menumbuhkan minat baca bagi siswa/siswinya.

Kegiatan pengabdian kepada masyarakat dilakukan penyuluhan tentang minat membaca anak. Di dalam penyampaian kegiatan pengabdian kepada masyarakat ini, tim pengabdi mengajak orang tua dalam memiliki peran sangat penting dalam kehidupan anak teristimewa dalam mengembangkan minat baca pada anak. Orangtua memiliki tugas mulia dalam rangka menciptakan generasi masa depan bangsa dan agama yang cerdas, beriman dan berakhlak mulia. Dapat dikatakan bahwa orangtua menjadi motivator yang sangat penting dalam mengembangkan minat membaca siswa. Apalagi ditengah pandemic Covid-19 membutuhkan peran dan bimbingan orangtua untuk selalu mengarahkan anak belajar di rumah.

Adapun kegiatan pengabdian kepada masyarakat digambarkan pada gambar 1 berikut.

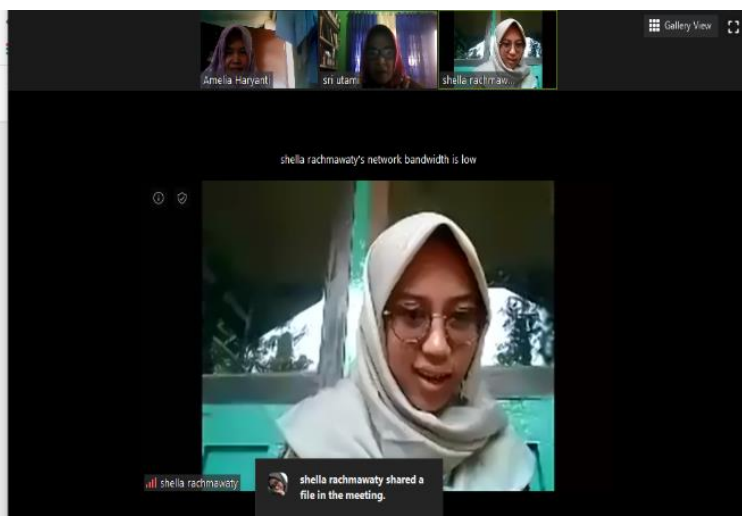

Sumber: Dokumentasi Penulis, 2020

Gambar 1. Kegiatan Pengabdian kepada Masyarakat

Gambar 1 menunjukkan kegiatan pengabdian kepada masyarakat dengan melakukan interaktif kepada narasumber dengan orangtua murid dalam upaya menumbuhkan minat baca anak. Dalam kegiatan pengabdian kepada masyarakat ini juga disertai dengan tanya jawab peserta penyuluhan kepada narasumber tentang permasalahan yang selama ini dihadapi oleh masyarakat teruma untuk menumbuhkan minat baca anak ditengah kecanggihan teknologi. Literasi dalam pembelajaran sangat penting untuk diberikan kepada peserta didik tidak hanya melalui teknologi namun literasi juga dapat dilakukan dengan cara meningkatkan minat membaca buku anak. Hal ini selaras dengan kajian yang dilakukan oleh Nursyifa (2019) peserta didik harus dapat menguasai literasi dalam pembelajaran. Tidak memandang anak masih PAUD sampai Perguruan Tinggi dituntut menguasai literasi, salah satunya dengan 
menumbuhkan minat membaca baik membaca buku, maupun literasi lewat media online.

Dalam kegiatan PkM ini diadakan tes untuk mengukur pemahaman peserta PkM dalam upaya menyerap materi dari narasumber. Oleh karena itu, dilakukan tes sebelum dengan sesudah kegiatan pengabdian kepada masyarakat. Berdasarkan tes yang dilakukan maka didapatkan adanya peningkatan dalam minat baca sebesar $80 \%$ pada anak usia dini, khususnya di PAUD Al Amanah.

Meningkatkan peran guru dan orang tua dalam mensosialisasikan minat baca bagi anak usia PAUD

Orang tua menjadi penentu atas terbentuknya minat baca anak karena proses pendidikan pertama adalah di lingkungan keluarga, sehingga orang tua harus proaktif untuk menciptakan iklim yang mendukung terbentuknya minat baca, menyediakan sarana dan prasarana yang menunjang.

Sebab minat itu sendiri bukanlah sesuatu yang dimiliki anak begitu saja, melainkan sesuatu yang dapat dikembangkan sehingga orang tua harus mampu menjadi motivator bagi sang anak. Peran adalah bagian dari tugas utama yang harus dilakukan. Orang tua yang dimaksud di sini adalah ayah dan ibu kandung yang mempunyai tugas mendidikan anak-anak dalam keluarga. Menurut Abdusalam (2005) peran orang tua menjadi hal yang sangat penting dalam menumbuhkan minat baca anak karena orang tua adalah orang terdekat pertama, terutama seorang ibu di mana sejak terbentuknya konsepsi sampai berkembang embrio hingga anak lahir banyak berhubungan secara langsung dengan ibu secara fisik maupun psikis.

Hal tersebut sesuai dengan UndangUndang No. 10 Tahun 1992 tentang perkembangan kependudukan dan pembangunan keluarga yang menetapkan bahwa fungsi utama keluarga meliputi; (1) keagamaan; (2) sosial budaya; (3) kasih sayang reproduksi; (4) pendidikan dan sosialisasi; (5) ekonomi; (6) perlindungan; dan (7) pembangunan lingkungan.

Untuk membentuk keluarga yang harmonis, maka fungsi-fungsi tersebut harus diciptakan saling mendukung. Untuk itu, orang tua sebagai pihak yang bertanggung jawab harus mampu menjalankan fungsifungsi tersebut sebagaimana mestinya. Keberhasilan anaka-anak, termasuk pendidikannya sangat dipengaruhi oleh sejauh mana orang tua mampu memberi sumbangsih bagi proses pendidikan, karena lingkungan keluarga adalah proses pertama pendidikan anak. Sebagaimana Gilbert Highest menyatakan, bahwa kebiasaan yang 
dimiliki anak-anak sebagian besar terbentuk oleh pendidikan keluarga. Sejak bengun tidur hingga tidur kembali di malam hari, anakanak menerima pengaruh lingkungan keluarga (Dariyo:2007).

Orang tua berperan sebagai pendidik anak apabila orang tua mampu menciptakan iklim psikis yang gembira dan bahagia. Sehingga suasana rumah tangga penuh kehangatan, rasa aman, dan kasih sayang. Iklim psikologis penuh kehangatan, kasih sayang, dan rasa aman tersebut akan memberikan vitamin psikologis yang akan memberikan motivasi dalam tumbuh kembang anak menuju kedewasaan.

Ada dua hal penting bagi orang tua dalam hubungannya dengan anak, yaitu mengetahui hakikat perkembangan anak sehingga mereka mengerti bagaimana anak berkembang dalam hal kognisi, afeksi, moral, dan sosial.

Meningkatkan minat baca pada anak usia PAUD

Dalam Kamus Bahasa Indonesia, mengembangkan berarti membuka lebarlebar, membentangkan, menjadi besar, luas, dan menjadikan satu. Dalam konsep psikologi anak dikatakan bahwa yang dimaksud dengan anak adalah orang yang sedang berada dalam perkembangan; mental, lahir, bayi, anak usia tiga tahun pertama, anak usia lima tahun pertama, dan anak tengah (6-12 tahun). Mengembangkan berarti mendiskusikan, mengarahkan kepada yang lebih baik dan lebih utama dari sebelumnya.

Dasar awal anak sangat penting dan mendasari kenapa minat baca perlu dikembangkan sedini mungkin. Pertama, hasil belajar dari pengalaman awal memiliki peran dominan dalam perkembangan dan usia anak serta bimbingan awal yang baik akan menjadi pondasi bagi anak. Kedua, dasar awal akan berkembang menjadi kebiasaan. Ketiga, pola sikap dan perilaku yang dibentuk pada awal terhadap anak cenderung bertahan. Keempat, perubahan yang cepat dan bijaksana oleh orang tua yang dekat dengan anak akan membuat anak mau bekerjasama dengan mengadakan perubahan.

Perasaan senang itu biasanya akan menumbuhkan minat, apalagi jika diperkuat dengan sikap positif, maka minat akan berkembang dengan lebih baik seseorang yang senantiasa cenderung pada hal yang disenanginya biasanya timbul rasa suka terhadap aktivitas tersebut. Minat adalah kecenderungan yang agak menetap dan subjek merasa tertarik pada bidang atau hal tertentu dan merasa senang berkecimpung dalam bidang itu. Tumbuhnya rasa suka ini tentunya menjadi motivasi tersendiri untuk melakukan aktivitas tersebut. Minat merupakan sumber motivasi untuk 
melakukan apa yang mereka inginkan bila mereka bebas memilih.

Minat sebagai kesukaan terhadap kegiatan melebihi kegiatan lainnya. Ini berarti minat berhubungan dengan nilai-nilai yang seseorang mempunyai pilihan dalam hidupnya. Selanjutnya, minat merupakan suatu perangkat mental yang terdiri dari suatu campuran antara perasaan, harapan, pendirian, prasangka, rasa takut, atau kecenderungan kecenderungan lain yang mengarahkan seseorang kepada suatu pilihan tertentu. Minat merupakan salah satu dimensi dari aspek afektif yang banyak berperan juga dalam kehidupan seseorang, khususnya dalam kehidupan belajar seorang murid." Aspek afektif adalah aspek yang mengidentifikasi dimensi-dimensi perasaan dari kesadaran emosi, disposisi, dan kehendak yang mempengaruhi pikiran dan tindakan seseorang.

Definisi ini menjelaskan bahwa minat berfungsi sebagai daya penggerak yang mengarahkan seseorang melakukan kegiatan tertentu yang spesifik. Motivasi adalah sumber untuk mempertahankan minat terhadap kegiatan dan menjadikan kegiatan sangat menyenangkan (excitement).

Motivasi adalah sumber untuk mempertahankan minat terhadap kegiatan dan menjadikan kegiatan sangat menyenangkan (excitement). Sama dengan perangkat mental lainnya, minat dapat dilihat dan diukur dari respon yang dihasilkan. Minat adalah suatu keadaan mental yang menghasilkan respons diarahkan kepada suatu situasi atau objek tertentu yang menyenangkan dan memberi kepuasan.

$$
\text { Membaca merupakan suatu }
$$
keterampilan yang kompleks yang melibatkan serangkaian keterampilan yang lebih kecil lainnya. Membaca pada hakikatnya adalah suatu yang rumit yang melibatkan banyak hal, tidak sekedar melafalkan tulisan, tetapi juga melibatkan aktivitas visual, berpikir, psikolinguistik dan metakognitif. Menurut Slameto (2003) membaca adalah suatu proses membangun pemahaman dari teks yang tertulis.

Membaca adalah suatu keterampilan berbahasa yang kompleks, yang melibatkan serangkaian keterampilan yang lebih kecil lainnya. Aspek penting di dalam membaca, salah satunya keterampilan yang bersifat mekanik (mechanical skill) yang dianggap berada pada urutan yang lebih rendah (low order). Aspek ini mencakup: a. Pengenalan bentuk huruf b. Pengenalan unsur-unsur linguistik (fonem/morfem, kata, pola klausa, kalimat dan lain-lain). c. Pengenalan hubungan/korespondensi pola ejaan dan bunyi. d. Kecepatan membaca bertaraf lambat. 
Membaca merupakan salah satu kegiatan dalam proses belajar mengajar. Seorang guru akan mencapai tujuan yang sesuai dengan program yang diinginkan. Hernowo (2002), mengatakan bahwa: tujuan utama dalam membaca adalah untuk mencari serta memperoleh informasi, mencakup isian dan memahami makna bacaan. Maka erat sekali hubungannya dengan makna, tujuan atau intensif kita dalam membaca. membaca dapat disimpulkan sebagai suatu proses yang melibatkan penglihatan dan tanggapan untuk memahami bahan bacaan yang bertujuan untuk memperoleh informasi atau mendapatkan kesenangan. Membaca adalah suatu proses yang dilakukan serta dipergunakan pembaca untuk memperoleh pesan yang hendak disampaikan oleh penulis melalui media kata-kata atau bahasa lisan.

Menurut Adhim (2007), membaca adalah sebuah proses yang kompleks karena setiap aspek yang ada selama proses membaca juga sangat kompleks. Ada delapan aspek yang ada selama proses membaca, , yaitu; (1) aspek sensori, yakni aspek kemampuan memahami simbol-simbol tertulis, (2) aspek persepsi, yaitu aspek kemampuan menginterpretasi apa yang dipahami sebagai modal atau kata, (3) aspek urutan, yakni kemampuan mengikuti polapola aturan, logika, dan gramatikal teks, (4) aspek asosiasi, yaitu aspek kemampuan mengenal hubungan antara simbol dan bunyi, serta antara kata-kata yang dapat dipresentasikan, (5) aspek speriensial, yakni aspek kemampuan menghubungkan kata-kata dengan pengalaman yang telah dimiliki untuk mengingat apa yang telah dimiliki untuk memberikan makna kata itu, (6) aspek belajar, yaitu aspek kemampuan untuk mengingat apa yang telah dipelajari dan menghubungkannya dengan gagasan dan fakta baru, (7) aspek berpikir, yakni kemampuan untuk membuat inferensi dan evaluasi materi yang dipelajari, dan (8) aspek afeksi, yaitu aspek yang berkenaan dengan minat membaca yang berpengaruh terhadap keinginan membaca.

Ketika anak sedang membaca, ia sesungguhnya tidak hanya membangun kemampuan berpikirnya, tapi pada saat yanga sama anak sedang mengasah perasaannya sehingga secara keseluruhan anak yang sedang membaca adalah anak yang yang sedang membangun kepribadian dan intelektualnya (Tarigan. 2000). Oleh karena itu, ketika sebuah proses membaca berlangsung, saat itu seluruh aspek kejiwaan dapat dikatakan berproses.

Dengan adanya kegiatan PkM ini dapat menjadi langkah nyata bahwasanya permasalahan pendidikan anak bukan hanya menjadi tugas dan tanggung jawab guru, namun juga menjadi tugas dan tanggungjawab bersama untuk menjalin 
kerjasama antara keluarga, sekolah, masyarakat, dan pemerintah harus proaktif dan bekerjasama demi tercapainya tujuan mulia tersebut. Sebab teori tidak akan berarti apa-apa tanpa diaplikasikan secara baik dan benar. Untuk mendapatkan generasi masa depan yang diharapkan, maka pengembangan minat baca anak sejak dini, strategi serta program pengembangannya harus mendapatkan perhatian serius dari kita semua.

\section{KESIMPULAN}

Orang tua menjadi penentu atas terbentuknya minat baca anak karena proses pendidikan pertama adalah di lingkungan keluarga, sehingga orang tua harus proaktif untuk menciptakan iklim yang mendukung terbentuknya minat baca, menyediakan sarana dan prasarana yang menunjang. Sebab minat itu sendiri bukanlah sesuatu yang dimiliki anak begitu saja, melainkan sesuatu yang dapat dikembangkan sehingga orang tua harus mampu menjadi motivator bagi sang anak. Peran orang tua menjadi hal yang sangat penting dalam menumbuhkan minat baca anak karena orang tua adalah orang terdekat pertama, terutama seorang ibu di mana sejak terbentuknya konsepsi sampai berkembang embrio hingga anak lahir banyak berhubungan secara langsung dengan ibu secara fisik maupun psikis.
Betapa pentingnya peran orang tua dalam pendidikan anak-anaknya pada umumnya dan kebiasaan membaca pada khususnya. Sebab bagaimanapun baiknya mutu suatu sekolah kalau orang tua tidak proaktif dalam memperhatikan dan membantu anak-anaknya di rumah, maka anak itu tidak akan mencapai kemajuan sebagaimana yang diharapkan. Keberhasilan anak-anak, termasuk pendidikannya sangat dipengaruhi oleh sejauh mana orang tua mampu memberi sumbangsih bagi proses pendidikan, karena lingkungan keluarga adalah proses pertama pendidikan anak.

Banyak strategi dan cara yang dapat digunakan oleh orang tua dalam mengembangkan minat baca pada anakanaknya. Berikut ini penulis mengemukakan adapun beberapa strategi atau cara yang kiranya dapat diterapkan oleh orang tua dalam mengembangkan minat baca pada anak, yaitu: mengarahkan pada anak bahwa buku adalah acuan informasi, mengajak anak ke kebun binatang, menyarankan anak untuk menamai buku-buku koleksinya, memberikan buku tentang sesuatu hal yang dilihat di TV, mengajak ke toko buku atau perpustakaan, membelikan buku yang dapat menarik minat baca anak, membuat perpustakaan keluarga, memberikan hadiah (reward), menjadikan kegiatan membaca sebagai kebiasaan setiap hari. 


\section{REFERENSI}

Abdusalam, A. (2005). Mengembangkan Kreativitas Anak. Jakarta: Pustaka Al Kautsar.

Adhim, F. (2007). Membuat anak gila membaca, Bandung: Mizan.

Dariyo, A. (2007). Psikologi Perkembangan. Bandung: Rafika aditama.

Hawadi, A. (2001). Psikologi Perkembangan Anak (Mengenal Sifat, Bakat, dan Kemampuan Anak). Jakarta: Grasindo. Hernowo. (2002). Mengikat Makna: KiatKiat Ampuh Untuk Melejitkan Kemauan Plus Kemampuan Membaca dan Menulis Buku. Bandung: Penerbit Kaifa.

Nursyifa, A. (2019). Transformasi Pendidikan Ilmu Pengetahuan Sosial dalam Menghadapi Era Revolusi Industri 4.0. Jurnal Pendidikan Kewarganegaraan, 6(1), 51-64.

Slameto. (2003). Belajar dan Faktor- Faktor yang Mempengaruhinya. Jakarta : Rineka Cipta.

Tarigan, H.G. (2000). Membaca sebagai suatu Keterampilan Berbahasa. Bandung: Penerbit Angkasa. 